\title{
The Potensial of Fusarium sp. and Chaetomium sp. as Biological Control Agents of Five Broad-Leaf Weeds
}

\author{
Loekas Soesanto*, Endang Mugiastuti and Abdul Manan \\ Faculty of Agriculture, Universitas Jenderal Soedirman, Purwokerto, Indonesia \\ ${ }^{*}$ Corresponding author: lukassusanto26@gmail.com
}

\begin{abstract}
Weeds are a major problem in crop cultivation, either in food crops, horticulture, plantations or forests and cause a decrease in the quality and quantity of production. Weed biocontrol, especially by using plant pathogenic fungi, has received attention but is still lacking in application. The purpose of this study was to determine the potential of Fusarium sp. and Chaetomium sp. as biological control agents against five broad-leaf weeds (Asystasia gangetica L., Ageratum conyzoides L., Synendrella nodiflora (L.) Gaertn., Wedelia trilobata (L.) U.S. Hitchc. and Amaranthus spinosus L.). The variables observed were the incubation period, disease incidence, disease intensity, as well as weed fresh and dry weight. The results of this study showed that the two pathogenic fungi, Fusarium sp. and Chaetomium sp., can cause a more intensive disease in A. conizoides than A. spinosus. A. gangetica, S. nodiflora and W. trilobata; however, the fungi have not been able to inhibit the growth and kill the weeds. Therefore, improvement need to be done by modifying the media to increase the ability of fungi to control weeds.
\end{abstract}

Keywords: biological control; broad-leaf weeds; Chaetomium sp.; Fusarium sp.

Cite this as: Soesanto, L., Mugiastuti, E., \& Manan, A. (2020). The Potensial of Fusarium sp. and Chaetomium sp. as Biological Control Agents of Five Broad-Leaf Weeds. Caraka Tani: Journal of Sustainable Agriculture, 35(2), 299-307. doi: http://dx.doi.org/10.20961/carakatani.v35i2.35713

\section{INTRODUCTION}

Weed is a major problem that arises from the beginning of planting preparation until near harvest period in crop cultivation, particularly food crops, horticulture, plantations and forests (Qasem and Foy, 2001). According to Fatonah et al. (2013), the presence of weeds in the middle of cultivated plants can cause substantial losses in the form of a decrease in the quality and quantity of production. This happens because of the high competitiveness of weeds against cultivated plants or staple plants in obtaining nutrients, water, places and sunlight. Losses due to weeds in cultivated plants vary, depending on the type of plant, climate, type of weed and agricultural practices. According to Gharde et al. (2018), in India, the total actual economic loss of about
USD 11 billion was estimated attributable to weeds alone in 10 major crops viz. groundnut $(35.8 \%)$, soybean $(31.4 \%)$, green gram $(30.8 \%)$, pearl millet $(27.6 \%)$, maize $(25.3 \%)$, sorghum (25.1\%), sesame (23.7\%), mustard (21.4\%), direct-seeded rice $(21.4 \%)$, wheat $(18.6 \%)$ and transplanted rice (13.8\%). Weeds exhibited the economic yield losses to the wheat crop, which might range from $24 \%$ to $39.95 \%$ (Oad et al., 2007). The decline in crop yields due to weeds in Indonesia was estimated to reach $10-20 \%$ (Solahudin et al., 2010).

Weeds, based on the morphological characteristics, can be divided into narrow-leaf weeds and broad-leaf weeds. Various species of narrow leaf weeds found in maize and rice include Cynodon dactilon, Digitaria ciliaris, Axonopus compressus, Eleusine indica, Ischaemum

\footnotetext{
* Received for publication November 20, 2019

Accepted after corrections July 27, 2020
} 
timorense, Panicum repens, Paspalum conygatum, Ottochloa nodosa, Echinochloa crusgalli, Imperata cylindrica and Setaria sp. (Arif et al., 2011; Anwar et al., 2012; Golmohammadi et al., 2018). The most widely found broad leaf weed species are Tridax procumbens (L.), Emilia sonchifolia D.C ex Wight, Ageratum conoyzoides L. and Synedrella nodiflora (L.) Gaertn (Tjitrosoedirjo et al., 2010).

The presence of weeds gives a negative influence on plants because of its adverse nature, namely as an allelopathy, allelomediation and allelopoly (Qasem and Foy, 2001). Allelopathy is a chemical compound produced by plants through washing, root exudation, evaporation and the decay of plant organs and thus inhibiting growth and development, as well as reducing plant production (Mushtaq and Siddiqui, 2017). According to Pereira et al. (2016), weeds are also allelomediation and allelopolistic. Allelomediation is the role of weeds as a place to live for certain types of pests, while allelopoly is the nature of weeds monopolizing water, nutrients, $\mathrm{CO}_{2}, \mathrm{O}_{2}$ and sunlight for plants.

Weed control can be done mechanically, technically and chemically (Marpaung et al., 2013). There are negative effects of mechanical control on weeds, such as the required cost and time that can influence other crop operations, effectiveness that is highly dependent on weather and soil conditions and correct time of application, lower efficacy of intra-row weed control, required skilled labor and high capital cost (Cherati et al., 2011; Karmiłowicz, 2019). The chemical or herbicide control of weeds is more effective than other controlling techniques, but it can have a negative impact on the environment if not wisely performed. However, this raises various problems, including the high cost of supplying herbicides, environmental pollution, decreasing soil organic matter and weeds being tolerant of certain types of herbicides (Kraehmer et al., 2014). Weed control using herbicides applied in the field \pm only $20 \%$ hit the target, while the other $8 \%$ fell, accumulated and left residue in the soil. The accumulation causes pollution on agricultural land. With the high level of danger of herbicides, it is necessary to look for the alternative controlling techniques called biological control (Latifa et al., 2015) that are environmentally friendly.

Weed biocontrol, especially by using plant pathogenic fungi, has recently received serious attention from the researchers in developed countries, because it has minimum negative side effects on the environment (Currie et al., 2020). Weed biological control is advantageous because it is environmentally friendly, reduces the use of pesticides, decreases environmental contamination, avoids health risks for farmers, is permanent, saves energy, does not pollute and is inexpensive compared to other methods and is sustainable (Harding and Raizada, 2015). In addition, biological control of weeds, especially by groups of fungi, has a high specificity (Harding and Raizada, 2015; Radi and BanaeiMoghaddam, 2020). However, weed control by using this pathogenic fungus is still lacking. The research on pathogenic fungi to control broad-leaf weeds has been initially carried out by exploring the fungus on broad-leaf weeds in the field and furthermore, the fungus needs to be tested for virulence on several broad-leaf weeds. This study aims to determine the potential of Fusarium sp. and Chaetomium sp. as biological control agents against five broad-leaf weeds.

\section{MATERIALS AND METHOD}

The research was carried out at the screen house, the Faculty of Agriculture, University of Jenderal Soedirman, Purwokerto, Indonesia, from March to August 2019. A split plot design was used with the main plot of a type of pathogens, including control, Fusarium sp. and Chaetomium sp. and subplots of five broad-leaf weeds, consisting of Asystasia gangetica L. (chinese violet, Acanthaceae), Ageratum conyzoides L. (billygoat-weed, Asteraceae), Synendrella nodiflora (L.) Gaertn. (nodeweed, Asteraceae), Wedelia trilobata (L.) U.S. Hitchc. (Bay Biscayne creeping oxeye, Asteraceae) and Amaranthus spinosus L. (spiny amaranth, Amaranthaceae). Based on these treatments, 15 treatment combinations were obtained and each treatment combination was repeated three times.

The propagation of pathogenic fungi was carried out with potato dextrose broth (PDB). A total of 5 cork of fungal culture isolates $( \pm 5 \mathrm{~mm}$, diameter) in a Potato dextrose agar (PDA) were put into $250 \mathrm{ml}$ of PDB and shaker for 7 days at $150 \mathrm{rpm}$ in room temperature. The target weed used in the test was grown in polybags containing soil media and manure $(3: 1)$ and allowed to grow for 14 days. The application of pathogenic fungi was carried out when the target weed was 14 days 
by spraying on the underside of the leaf (Gudesblat et al., 2009). The density of the pathogenic fungus used was $1 \times 10^{7}$ conidia $\mathrm{mL}^{-1}$.

The variables observed were the incubation period, disease incidence, disease intensity, weed fresh weight and weed dry weight. The incubation period was observed from inoculation until the initial symptoms appeared. The disease incidence was calculated using the formula (Noordzij et al., 2010):

$$
D I=\frac{n}{N} \times 100 \%
$$

Where DI $=$ disease incidence; $\mathrm{n}=$ number of diseased plants; and $\mathrm{N}=$ number of observed plants. The disease intensity was monitored weekly using the formula:

$$
D N=\sum \frac{n \times v}{Z \times N} \times 100 \%
$$

where DN = disease intensity; $\mathrm{n}=$ number of leaves in certain disease symptom categories; $\mathrm{v}=$ scale value in each category of disease symptoms; $\mathrm{Z}=$ highest scale value of disease symptom category; and $\mathrm{N}=$ number of leaves observed. The scale values of disease symptoms were determined as presented in Table 1 .

The number of seeds produced by weeds, fresh weights and dry weights were measured at the end of the research activities. The data obtained were analyzed using the $\mathrm{F}$ test at $\alpha 5 \%$, if there was a real improvement followed by Duncan's Multiple Range Test (DMRT) with $\alpha 5 \%$.
Table 1. Score value (Asmaliyah et al., 2016)

\begin{tabular}{cl}
\hline $\begin{array}{c}\text { Score } \\
\text { value }\end{array}$ & \multicolumn{1}{c}{ Disease symptom level } \\
\hline 0 & No disease symptom (healthy plants) \\
1 & Disease symptom $\leq 10 \%$ \\
2 & Disease symptom $11<\mathrm{x} \leq 25 \%$ \\
3 & Disease symptom $26<\mathrm{x} \leq 50 \%$ \\
4 & Disease symptom $51<\mathrm{x} \leq 75 \%$ \\
5 & Disease symptom $>756 \%$ \\
\hline
\end{tabular}

\section{RESULTS AND DISCUSSION}

The pathogenic fungi caused some symptoms on weeds. Leaf blights, leaf spots, root rot and anthracnose were the common symptoms attributed to fungal pathogens tested on different parts of the weeds. Table 2 indicates that single treatment, with either pathogenic fungi or kind of weeds and the combination treatment between pathogenic fungi and kind of weeds performed significantly difference for the incubation period and differed disease intensity and diseased incidence. The kind of weed as a single treatment influenced all pathosystems and growth components significantly. Meanwhile, the pathogenic fungi and their combination with kind of weeds differed at disease intensity and incidence but they did not differ significantly at growth components. The virulent tests of these pathogens had been done on cultivated plants, namely tomatoes, peanuts and cucumbers. The results of the testing of the two fungi (Fusarium and Chaetomium) were not able to cause disease to the three plants.

Table 2. The results of a variety of influences of pathogenic fungi on five types of broad-leaf weeds

\begin{tabular}{lccc}
\hline \multicolumn{1}{c}{ Variable } & $\mathrm{C}$ (pathogenic fungi) & $\mathrm{G}($ weeds $)$ & $\mathrm{CXG}$ \\
\hline Incubation period & $* *$ & $* *$ & $* *$ \\
Disease intensity & $*$ & $* *$ & $*$ \\
Disease incidence & $*$ & $* *$ & $*$ \\
Weeds fresh weight & $\mathrm{ns}$ & $* *$ & $\mathrm{~ns}$ \\
Weeds dry weight & $\mathrm{ns}$ & $* *$ & $\mathrm{~ns}$ \\
\hline
\end{tabular}

Note: $*=$ different $; * *$ significantly different; $\mathrm{ns}=$ not significantly different

\section{Single treatment of weed pathogenic fungi}

The single treatment of Fusarium sp. and Chaetomium sp. was not different in the incubation period (Table 3). It is suspected that both weed pathogenic fungi have the same virulence in causing symptoms of the disease. This condition corresponds to the intensity of the disease and the incidence of the disease (Table 3). The ability of both pathogenic fungi shows the same virulence to cause disease symptoms in the same test weed. It is deduced that these two fungi are pathogenic fungi on weeds because the fungi could perform symptoms and caused diseases. According to Casadevall (2007) and Longdon et al. (2015), virulent 
pathogens are able to quickly infect their host and produce more inoculums when compared to less virulent pathogens. It is suspected that the fungus Fusarium sp. has infectious ability and is supported by the ability of Fusarium enzymes to degrade weed cells.

Table 3. The incubation period, disease incidence, disease intensity, weed fresh weight and weed dry weight in the virulence test of wide-leaf weed pathogenic fungi

\begin{tabular}{|c|c|c|c|c|c|}
\hline Treatments & $\begin{array}{c}\text { Incubation } \\
\text { period } \\
\text { (DAI) }\end{array}$ & $\begin{array}{l}\text { Disease } \\
\text { incidence } \\
(\%)\end{array}$ & $\begin{array}{l}\text { Disease } \\
\text { intensity } \\
(\%)\end{array}$ & $\begin{array}{c}\text { Weeds fresh } \\
\text { weight } \\
\text { (g) }\end{array}$ & $\begin{array}{l}\text { Weeds dry } \\
\text { weight } \\
\text { (g) }\end{array}$ \\
\hline \multicolumn{6}{|l|}{ Pathogenic fungi } \\
\hline Control (C0) & $42.00 \mathrm{a}$ & $0.00 \mathrm{~b}$ & $0.00 \mathrm{a}$ & $31.28 \mathrm{a}$ & $5.81 \mathrm{a}$ \\
\hline Fusarium sp. (C1) & $12.98 \mathrm{~b}$ & $10.69 \mathrm{ab}$ & $6.17 b$ & $32.02 \mathrm{a}$ & $4.60 \mathrm{a}$ \\
\hline Chaetomium sp. (C2) & $10.93 b$ & $13.18 \mathrm{a}$ & $7.35 b$ & $30.42 \mathrm{a}$ & $4.63 \mathrm{a}$ \\
\hline \multicolumn{6}{|l|}{ Kind of weeds } \\
\hline Asystasia gangetica $(\mathrm{G} 1)$ & $18.89 \mathrm{~b}$ & $10.13 \mathrm{ab}$ & $2.10 \mathrm{~b}$ & $31.78 \mathrm{bc}$ & $4.46 \mathrm{ab}$ \\
\hline Ageratum conyzoides $(\mathrm{G} 2)$ & $17.48 \mathrm{~b}$ & $18.48 \mathrm{a}$ & $14.43 \mathrm{c}$ & $10.70 \mathrm{c}$ & $2.62 \mathrm{~b}$ \\
\hline Synedrella nodiflora (G3) & $16.93 b$ & $6.20 \mathrm{~b}$ & $1.93 b$ & $38.56 \mathrm{ab}$ & $6.21 \mathrm{ab}$ \\
\hline Wedelia trilobata (G4) & $39.26 \mathrm{a}$ & $0.48 \mathrm{~b}$ & $0.23 \mathrm{a}$ & $18.62 \mathrm{bc}$ & $2.44 \mathrm{~b}$ \\
\hline Amaranthus spinosus (G5) & $17.20 \mathrm{~b}$ & $4.50 \mathrm{~b}$ & $3.84 \mathrm{~b}$ & $56.56 \mathrm{a}$ & $9.33 \mathrm{a}$ \\
\hline \multicolumn{6}{|c|}{ Combination of the fungi and weeds } \\
\hline C0G1 & $42.00 \mathrm{a}$ & $0.00 \mathrm{c}$ & $0.00 \mathrm{a}$ & $28.56 \mathrm{a}$ & $3.52 \mathrm{a}$ \\
\hline $\mathrm{C} 0 \mathrm{G} 2$ & $42.00 \mathrm{a}$ & $0.00 \mathrm{c}$ & $0.00 \mathrm{a}$ & $7.00 \mathrm{a}$ & $3.15 \mathrm{a}$ \\
\hline COG3 & $42.00 \mathrm{a}$ & $0.00 \mathrm{c}$ & $0.00 \mathrm{a}$ & $42.00 \mathrm{a}$ & $6.29 \mathrm{a}$ \\
\hline C0G4 & $42.00 \mathrm{a}$ & $0.00 \mathrm{c}$ & $0.00 \mathrm{a}$ & $15.53 \mathrm{a}$ & $2.23 \mathrm{a}$ \\
\hline C0G5 & $42.00 \mathrm{a}$ & $0.00 \mathrm{c}$ & $0.00 \mathrm{a}$ & $63.33 \mathrm{a}$ & $13.86 \mathrm{a}$ \\
\hline C1G1 & $8.00 \mathrm{c}$ & $12.06 \mathrm{bc}$ & $2.80 \mathrm{~cd}$ & $38.56 \mathrm{a}$ & $5.39 \mathrm{a}$ \\
\hline $\mathrm{C} 1 \mathrm{G} 2$ & $5.56 \mathrm{c}$ & $25.92 \mathrm{a}$ & $21.10 \mathrm{e}$ & $10.78 \mathrm{a}$ & $2.17 \mathrm{a}$ \\
\hline $\mathrm{C} 1 \mathrm{G} 3$ & $4.44 \mathrm{c}$ & $7.39 \mathrm{bc}$ & $3.29 \mathrm{~cd}$ & $45.33 \mathrm{a}$ & $7.61 \mathrm{a}$ \\
\hline C1G4 & $42.00 \mathrm{a}$ & $0.00 \mathrm{c}$ & $0.00 \mathrm{a}$ & $19.22 \mathrm{a}$ & $2.40 \mathrm{a}$ \\
\hline C1G5 & $4.89 c$ & $8.09 \mathrm{bc}$ & $3.68 \mathrm{~d}$ & $46.22 \mathrm{a}$ & $5.42 \mathrm{a}$ \\
\hline $\mathrm{C} 2 \mathrm{G} 1$ & $6.67 c$ & $18.34 \mathrm{ab}$ & $3.51 \mathrm{~cd}$ & $28.22 \mathrm{a}$ & $4.47 \mathrm{a}$ \\
\hline $\mathrm{C} 2 \mathrm{G} 2$ & $4.89 \mathrm{c}$ & $29.51 \mathrm{a}$ & $22.19 \mathrm{e}$ & $14.33 \mathrm{a}$ & $2.54 \mathrm{a}$ \\
\hline $\mathrm{C} 2 \mathrm{G} 3$ & $4.33 c$ & $11.20 \mathrm{bc}$ & 2.51abcd & $28.33 \mathrm{a}$ & $4.73 a$ \\
\hline C2G4 & $33.78 \mathrm{~b}$ & $1.44 \mathrm{c}$ & $0.70 a b c$ & $21.11 \mathrm{a}$ & $2.70 \mathrm{a}$ \\
\hline C2G5 & $5.00 \mathrm{c}$ & $5.42 \mathrm{c}$ & $7.84 \mathrm{~d}$ & $60.11 \mathrm{a}$ & $8.71 \mathrm{a}$ \\
\hline
\end{tabular}

Note: Numbers followed by the same letters in the same column and the same type of treatment are not significantly different based on DMRT $\alpha 5 \%$; DAI = day after inoculation

This is in line with the results of study by Michielse and Martijn (2009) that $F$. oxysporum can damage plant tissues because it produces enzymes that degrade compounds contained in cells. Sun et al. (2014) added that Fusarium sp. can produce enzymes $\beta$-glucosidase, amylase, pectinase, silanase and cellulase (Dwivedi and Enespa, 2015; Basak and Rangan, 2018). The existence of these enzymes causes damage to host plant cells because they can break down pectin, which is a component of cell walls. In addition, the cellulolysis enzymes degrade cell membranes in plant tissue, which can cause damage and disease in host plants. Meanwhile, pathogenic fungus Chaetomium sp. as an antagonistic fungus are found in various habitats (Sunayana and Prakash, 2012). This fungus is known to produce lysis enzymes and many other secondary metabolites involved in its virulence mechanism (Zhang et al., 2012). Al-Kharousi et al. (2015) reported that the fungus Chaetomium sp. produce cellulase enzymes that degrade cellulosic biomass.

Both weed pathogenic fungi produce enzymes lysis of very complex plant biomass, which mainly contains cellulose. Lignocellulose biomass degradation requires a sophisticated set of enzymes. The complexity of carbohydrate 
polymers and their cross-linking with lignin require a complex set of enzymes to allow polysaccharide access and release fermentable sugars. Lignocellulose basically consists of plant cell wall components (Mota et al., 2018). In contrast, the two fungi alone had no effect on the components of weed growth, i.e., weeds fresh and dry weights, when compared to control (Table 3 ). In addition, the presence of a barrier factor or structural resistance on the surface of weed leaves can cause low pathogenic fungal infections (Caffall and Mohnen, 2009).

\section{Single treatment of weed types}

In Table 3, it appears that the type of weed affected the component of the pathosystem. Wedelia trilobata showed the fastest incubation period compared to other weeds. Wedelia trilobata had the longest incubation period of 39.259 DAI. According to Qi et al. (2014), this is presumably because Wedelia trilobata has the thickest leaf thickness among all weeds so that pathogens require a little longer time to infect the weeds. In addition, Wedelia trilobata is a plant that has allelopathic properties. This causes Wedelia trilobata to become less susceptible to inoculated pathogenic fungi and these weeds can fight independently in their own tissues using secondary metabolites such as phenolic, terpenoids, alkaloids, steroids, polyacetylene and essential oils that drive allelopathic activity (Xianxing et al., 2005). The weed has wider and thinner leaves, so it is infectious on physiological properties, leaf area allocation, bud allocation and growth rate so that the leaves morphology can influence photosynthesis rate, transpiration, nitrogen content in leaf tissue, efficient use of nitrogen and efficient use of water ( $\mathrm{Wu}$ et al., 2012).

Although Wedellia trilobata was shown the most infectious, the development of symptoms of the weeds indicated low disease intensity, when compared with other weeds (Table 3). Ageratum conyzoides actually exhibited a higher disease incidence and disease intensity than other weeds and was significantly different from Synedrella nodiflora, Wedelia trilobata and Amaranthus spinosus. A. conyzoides have amphistomata properties, with stomata anomositis and anisositis, being the first more commonly found (Santos et al., 2016). The large number of stomata causes these weeds to be more easily infected by the pathogenic fungus conidia. According to Sexto and Howlett (2006), some fungal pathogens enter the host via natural openings (stomata of plants) or even wounds, whereas others secrete toxins and/or enzymes, apply mechanical force, or subvert cellular processes of the host.

This is consistent with the opinion of Gudesblat et al. (2009) and Zeng et al. (2010), that fungal and bacterial pathogens enter and infect the leaves through the stomata, which is shown in a lot of tropical movements towards the stomata. After the infection, microbes can influence stomata behavior in a variety of ways, a fact that is associated with interactions between fungi and plant compounds secreted during plant pathogen interactions. This is supported by disease intensity data (Table 3), which show that the disease intensity in A. conyzoides was higher and significantly different compared to all tested weeds.

According to Dalimartha (2002), Ageratum conyzoides has thin leaves covered with feathers or hairs (trichomes) on the upper and lower surface of the leaf. The presence of hairs or feathers is one of the factors driving the pathogen infection. The presence of these hairs or feathers allows the pathogen to stick to the hairs or feathers and the pathogen penetrates the lower surface of the leaf, enters the host plant's body tissue and then infects its host plant (Ogbonna and Umunna, 2017). A. conyzoides indicated as more susceptible weed resulted the high disease intensity and the disease incidence. The infection of pathogenic fungi to plants is also affected by the pathogenic virulence and suitable environments for the pathogen development (Chakraborty and Newton, 2011; Velásquez et al., 2018). For A. conyzoides, the wide-leaf size will increase moisture under a high canopy, which allows pathogenic fungi to grow and develop, as well as infect plants (Gudesblat et al., 2009). This is supported that $A$. conyzoides has the low weight of wet and dry weeds, which are significantly different from other weeds. The decrease in wet and dry weeds of A. conyzoides is not entirely due to the morphological characteristics of the weeds, but also from pathogenic fungal infections. This is in line with more stomata found on A. conyzoides than other weeds (Santos et al., 2016).

\section{Treatment combination of pathogenic fungi and weeds}

The combination between $A$. conyzoides and Fusarium sp. and Chaetomium sp. exerted 
a highly significant effect on all components of the ecosystem compared to the other combinations (Table 3). This is consistent with the single treatment. The ability of weed pathogenic fungi to infect weeds is due to their ability to produce a number of enzymes, specifically cellulose degrading enzymes, which are compounds making up leaf cell walls (Dwivedi and Enespa, 2015; Basak and Rangan, 2018). In addition, the morphological weed leaves also determines the success infection of weed pathogenic fungal by developing the disease symptoms. The infection of fungal microbes to attack plant tissues has many strategies, to optimize growth and to multiply themselves. Bacteria and viruses, as well as some opportunistic fungal parasites, often depend on natural holes or wounds for invasion. In contrast, many true phytopathogenic fungi have developed mechanisms to actively cross barriers to the outer structure of plants, cuticles and cell walls of the epidermis. Fungi generally secrete a number of hydrolysis enzymes, including cutaneous, cellulase, pectinase and protease (Uzma et al., 2016).

\section{CONCLUSIONS}

The two pathogenic fungi, Fusarium sp. and Chaetomium sp., can cause greater disease in A. conizoides than A. spinosus. A. gangetica, $S$. nodiflora and $W$. trilobata. However, the fungi have not been able to inhibit the growth of weeds and kill them and hence, the media need to be modified to improve ability of fungi to control weeds.

\section{ACKNOWLEDGEMENT}

Thanks to the Ministry of Research, Technology and Higher Education of the Republic of Indonesia for the financial support through the National Competitive Research 2019-2021. Gratitude is also addressed to Yulia Rizki Mualina for the technical assistance.

\section{REFERENCES}

Al-Kharousi, M. M., Sivakumar, N., \& Elshafie, A. (2015). Characterization of cellulase enzyme produced by Chaetomium sp. isolated from books and archives. EurAsian Journal of BioSciences, 9, 52-60. https://doi.org/10.5053 /ejobios.2015.9.0.7
Anwar, M. P., Juraimi, A. S., Samedani, B., Puteh, A., \& Man, A. (2012). Critical period of weed control in aerobic rice. The Scientific World Journal, 2012, 1-10. https://doi.org/10.1100/ 2012/603043

Arif, M., Mukhtar, T., Rahman, S. U., Hussain, K., Razaq, A., \& Iqbal, R. A. (2011). Efficacy of different herbicides against weeds in maize (Zea mays L.). Pakistan Journal of Weed Science, 17(2), 125-133. Retrieved from https://www.researchgate.net/publication/270 392838_EFFICACY_OF_DIFFERENT_HER BICIDES_AGAINST_WEEDS_IN_MAIZE_ Zea_maysL

Asmaliyah, A., Lukman, H., \& Mindawati, N. (2016). Pengaruh teknik persiapan lahan terhadap serangan hama penyakit pada tegakan bambang lanang. Jurnal Penelitian Hutan Tanaman, 13(2), 139-155. https://doi.org/ 10.20886/jpht.2016.13.2.139-155

Basak, S., \& Rangan, L. (2018). Production, characterization and inhibition of fungal cellulases utilizing rice bran as substrate in solid state fermentation. Microbiology: Current Research, 2(4), 69-74. https://doi.org/ 10.35841/2591-8036.18-821

Caffall, K. H., \& Mohnen, D. (2009). The structure, function and biosynthesis of plant cell wall pectic polysaccharides. Carbohydrate Research, 344, 1879-1900. https://doi.org/ 10.1016/j.carres.2009.05.021

Casadevall, A. (2007). Determinants of virulence in the pathogenic fungi. Fungal Biology Reviews, 21(4), 130-132. https://doi.org/ 10.1016/j.fbr.2007.02.007

Chakraborty, S., \& Newton, A. C. (2011). Climate change, plant diseases and food security: an overview. Plant Pathology, 60, 2-14. https:// doi.org/10.1111/j.1365-3059.2010.02411.x

Cherati, F. E., Bahrami, H., \& Asakereh, A. (2011). Evaluation of traditional, mechanical and chemical weed control methods in rice fields. Australian Journal of Crop Science, 5(8), 1007-1013. Retrieved from http://www. cropj.com/cherati_5_8_2011_1007_1013.pdf

Currie, A. F., Gange, A. C., Ab Razak, N., Ellison, C. A., Maczey, N., \& Wood, S. V. (2020). Endophytic fungi in the invasive weed Impatiens glandulifera : a barrier to classical 
biological control? Weed Research, 60(1), 5059. https://doi.org/10.1111/wre.12396

Dalimartha, S. (2002). Ramuan tradisional untuk pengobatan kanker. Jakarta: PT Penebar Swadaya.

Dwivedi, S. K., \& Enespa. (2015). In vitro cellulase activity of two wilt causing soil fusaria (Fusarium solani and F. oxysporum f.sp. lycopersici) and efficacy of some pesticides against the said fusaria. Journal of Applied Horticulture, 17(1), 58-65. https:// doi.org/10.37855/jah.2015.v17i01.12

Fatonah, S., Asih, D., Mulyanti, D., \& Iriani, D. (2013). Penentuan waktu pembukaan stomata pada gulma Melastoma malabathricum L. di Perkebunan Gambir Kampar, Riau. Jurnal Biospecies, 6(2), 15-22. https://doi.org/ 10.1017/CBO9781107415324.004

Gharde, Y., Singh, P. K., Dubey, R. P., \& Gupta, P. K. (2018). Assessment of yield and economic losses in agriculture due to weeds in India. Crop Protection, 107, 12-18. https:// doi.org/10.1016/j.cropro.2018.01.007

Golmohammadi, M. J., Chamanabad, H. R. M., Yaghoubi, B., \& Oveisi, M. (2018). Study of postharvest weed population in paddy fields. Sarhad Journal of Agriculture, 34(2), 395399. https://doi.org/10.17582/journal.sja/2018 /34.2.395.399

Gudesblat, G. E., Torres, P. S., \& Vojno, A. A. (2009). Stomata and pathogens: Warfare at the gates. Plant Signaling \& Behavior, 4(12), 1114-1116. https://doi.org/10.4161/psb.4.12. 10062

Harding, D. P., \& Raizada, M. N. (2015). Controlling weeds with fungi, bacteria and viruses: a review. Frontiers in Plant Science, 6, 659. https://doi.org/10.3389/fpls.2015.006 59

Karmiłowicz, E. (2019). The use of herbicides to regulate weeds in forest nurseries and crops in Poland. Folia Forestalia Polonica, Series A, 61(3), 222-229. https://doi.org/10.2478/ffp2019-0021

Kraehmer, H., van Almsick, A., Beffa, R., Dietrich, H., Eckes, P., Hacker, E., Hain, R., Strek, H. J., Stuebler, H., \& Willms, L. (2014). Herbicides as weed control agents: State of the
Art: II. Recent achievements. Plant Physiology, 166(3), 1132-1148. https://doi. org/10.1104/pp.114.241992

Latifa, R. Y., Maghfoer, M. D., \& Widaryanto, E. (2015). Pengaruh pengendalian gulma terhadap tanaman kedelai (Glycine max (L.) Merril) pada sistem olah tanah. Jurnal Produksi Tanaman, 3(4), 311-320. Retrieved from http://protan.studentjournal.ub.ac.id/inde x.php/protan/article/view/205

Longdon, B., Hadfield, J. D., Day, J. P., Smith, S. C. L., McGonigle, J. E., Cogni, R., Cao, C., \& Jiggins, F. M. (2015). The causes and consequences of changes in virulence following pathogen host shifts. PLoS Pathog., 11(3), e10047. https://doi.org/10.1371/journal. ppat. 1004728

Marpaung, I., Parto, Y., \& Sodikin, E. (2013). Evaluasi kerapatan tanam dan metode pengendalian gulma pada budidaya padi tanam benih langsung di lahan sawah pasang surut. Jurnal Lahan Suboptimal, 2(1), 93-99. Retrieved from http://www.jlsuboptimal. unsri.ac.id/index.php/jlso/article/view/48

Michielse, C. B., \& Martijn, R. E. P. (2009). Pathogen profile update: Fusarium oxysporum. Plant Pathology, 10(3), 311-324. https://doi.org/10.1111/j.1364-3703.2009.005 38. $\mathrm{x}$

Mota, T. R., de Oliveira, D. M., Marchiosi, R., Ferrarese-Filho, O., \& dos Santos, W. D. (2018). Plant cell wall composition and enzymatic deconstruction. AIMS Bioengineering, 5(1), 63-77. https://doi.org/ 10.3934/bioeng.2018.1.63

Mushtaq, W., \& Siddiqui, M. B. (2017). Allelopathy studies in weed science in IndiaA review. International Journal of Natural Resource Ecology and Management, 2(6), 99103. https://doi.org/10.11648/j.ijnrem.201702 06.11

Noordzij, M., Dekker, F. W., Zoccali, C., \& Jager, K. J. (2010). Measures of disease frequency: prevalence and incidence. Nephron Clinical Practice, 115, 17-20. https://doi.org/10.1159/ 000286345

Oad, F. C., Siddiqui, M. H., \& Buriro, U. A. (2007). Growth and yield losses in wheat due to different weed densities. Asian Journal of 
Plant Sciences, 6(1), 173-176. https://doi.org/ 10.3923/ajps.2007.173.176

Ogbonna, M. J., \& Umunna, O. E. (2017). Pathogen penetration into the host plant tissues challenges and obstacles - An overview. Scholars Journal of Agriculture and Veterinary Sciences, 4(5), 178-185. Retrieved from https://www.researchgate.net/publicatio n/329717833_Pathogen_Penetration_into_the _Host_Plant_Tissues_Challenges_and_Obsta cles-An_Overview

Pereira, I., Dias, A., \& Dias, L. (2016). Defensive role of allelopathic secondary compounds in plants I: testing two independent general hypotheses. Journal of Negative Results, 11(1), 10-24. Retrieved from http://j_allel_ inter.webs.uvigo.es/images/issues/volume41/JAI_Volume4-1_article1.pdf

Qasem, J. R., \& Foy, C. L. (2001). Weed Allelopathy, Its Ecological Impacts and Future Prospects. Journal of Crop Production, 4(2), 43-119. https://doi.org/10.1300/J144v04 n02_02

Qi, S.-S., Dai, Z.-C., Miao, S.-L., Zhai, D.-L., Si, C.-C., Huang, P., Wang, R.-P., \& Du, D.-L. (2014). Light limitation and litter of an invasive clonal plant, Wedelia trilobata, inhibit its seedling recruitment. Annals of Botany, 114(2), 425-433. https://doi.org/ 10.1093/aob/mcu075

Radi, C. H., \& Banaei-Moghaddam, M. A. (2020). Biological control of weeds by fungi: challenges and opportunities. Acta Scientific Microbiology, 3(5), 62-70. https://doi.org/ 10.31080/asmi.2020.03.0590

Santos, R. F., Nunes, B. M., Sá, R. D., Soares, L. A. L., \& Randau, K. P. (2016). Morphoanatomical study of Ageratum conyzoides. Revista Brasileira de Farmacognosia, 26(6), 679-687. https://doi.org/10.1016/j.bjp.2016.0 7.002

Sexto, A. C. \& Howlett, B. J. (2006). Parallels in fungal pathogenesis on plant and animal hosts. Eukaryotic Cell, 5(12), 1941-1949. https://doi. org/10.1128/EC.00277-06

Solahudin, M., Seminar, K. D., Astika, I. W., \& Buono, A. (2010). Pendeteksian kerapatan dan jenis gulma dengan metode bayes dan analisis dimensi fraktal untuk pengendalian gulma secara Selektif. Journal Keteknikan Pertanian, 24(2), 129-136. https://doi.org/10.19028/ jtep.24.2.129-136

Sun, Y., Yi, X., Peng, M., Zeng, H., Wang, D., Li, B., Tong, Z., Chang, L., Jin, X., \& Wang, X. (2014). Proteomics of Fusarium oxysporum race 1 and race 4 reveals enzymes involved in carbohydrate metabolism and ion transport that might play important roles in banana Fusarium wilt. PLOS ONE, 9(12), 1-20. https://doi.org/10.1371/journal.pone.01 13818

Sunayana, N., \& Prakash, H. S. (2012). Fungal endophytes of Boswellia serrata Roxb. (Burseraceae), a medicinal tree species. IOSR Journal of Pharmacy and Biological Sciences, 1(6), 1-5. https://doi.org/10.9790/3008-016 0105

Tjitrosoedirjo, Sudarmiyati, S., Hidayat, U., \& Joedojono, W. (2010). Pengelolaan gulma di lahan perkebunan. Jakarta: Gramedia.

Uzma, F., Konappa, N. M., \& Chowdappa, S. (2016). Diversity and extracellular enzyme activities of fungal endophytes isolated from medicinal plants of Western Ghats, Karnataka. Egyptian Journal of Basic and Applied Sciences, 3(4), 335-342. https://doi.org/ 10.1016/j.ejbas.2016.08.007

Velásquez, A. C., Castroverde, C. D. M., \& He, S. Y. (2018). Review plant - Pathogen warfare under changing climate conditions. Current Biology, 28(10), 619-634. https://doi.org/ 10.1016/j.cub.2018.03.054

Wu, W., Zhou, R., Ni, G., Shen, H., \& Ge, X.-J. (2012). Is a new invasive herb emerging? Molecular confirmation and preliminary evaluation of natural hybridization between the invasive Sphagneticola trilobata (Asteraceae) and its native congener $S$. calendulacea in South China. Biological Invasions, 15(1), 75-88. https://doi.org/ 10.1007/s10530-012-0269-y

Xianxing, C., Bingyang, D., Xiliang, S., \& Xianwu, H. (2005). The allelopathy of the water extract from Wedelia trilobata on several economic crops. Journal of Gansu Sciences, 17(4), 15-17. Retrieved from https://euro 
pepmc.org/article/cba/601518

Zeng, W., Melotto, M., \& He, S. Y. (2010). Plant stomata: a checkpoint of host immunity and pathogen virulence. Current Opinion in Biotechnology, 21(5), 599-603. https://doi. org/10.1016/j.copbio.2010.05.006
Zhang, Q., Li, H. Q., Zong, S. C., Gao, J. M., \& Zhang, A. L. (2012). Chemical and bioactive diversities of the genus Chaetomium secondary metabolites. Mini-Reviews in Medicinal Chemistry, 12(2), 127-148. https:// doi.org/10.2174/138955712798995066 